\title{
X-linked calvarial hyperostosis
}

INSERM

\section{Source}

INSERM. (1999). Orphanet: an online rare disease and orphan drug data base. $\underline{X \text {-linked }}$ calvarial hyperostosis. ORPHA:391327

X-linked calvarial hyperostosis is a rare, genetic, primary bone dysplasia with increased bone density disorder characterized by benign, isolated, calvarial thickening, presenting with prominent frontoparietal bones, a high forehead with ridging of the metopic and sagittal sutures, lateral frontal prominences, and facial dysmorphism comprising a flat nasal root and short, upturned nose. Increased intracranial pressure and cranial nerve entrapment are not associated. There have been no further descriptions in the literature since 1986. 